\title{
CSI Method of Assessing Patient Satisfaction in Selected Maternity Wards
}

\author{
Paulina Gajewska, Katarzyna Piskrzyńska \\ University of Bielsko-Biala, Poland
}

\begin{abstract}
Health care is an area in which all who are involved should try to ensure that the quality of the provision is at a high level, especially in maternity wards. The quality of these services is not only the competence of the medical staff, but the whole set of factors prevailing in the ward and in the hospital, from cleanliness of the delivery room to the staff courtesy of the institution. The article presents the results of research on clients' satisfaction with the quality of the services offered by the selected maternity ward in Provincial Hospital in Bielsko-Biala. Customer Satisfaction Index (CSI) method was used for analysis.
\end{abstract}

Keywords: Customer Satisfaction Index (CSI), satisfaction, health services

\section{Health Services}

Health is a specific value of detailed ethical dimension. It is not a commodity, health has no price - is priceless (Opolski, Dykowska, \& Możdżonek, 2005, p. 15). Due to its unique character, health services are among the outstanding products on the market. In no other sector of the economy such emphasis on professional ethics of the service provider is put. As early as the fourth century BC, Hippocrates suggested that the good of the patient should be the main principle of the doctor. He considered an ideal doctor to be in the service of the sick, expressing understanding for a patient and complying medical confidentiality. "Medical need is the difference between the observed (real), and the ideal level of health". Needs resulting from the use of health care products are varied. These include (Flejterski, Panasiuk, Perenc, \& Rosa, 2005, pp. 413-414):

(1) Saving lives;

(2) Maintaining good health, recovery, and the fight against disease;

(3) Better mood (including mental health) and looks;

(4) Disease prevention, prophylaxis.

The health services market is very wide and has both a public sector and a private sector. The public sector refers to all treatments provided by National Health Fund. The private sector collects money by charging patients for the execution of specific performance.

The growing importance of quality is recorded in all areas, so it is no wonder that more and more attention is being paid to the quality of health services. Life and health are the most precious gift of every human being.

Paulina Gajewska, Ph.D., Department of Management, Faculty of Management and Transport, University of Bielsko-Biala. Email: pgajewska@ath.bielsko.pl.

Katarzyna Piskrzyńska, Ph.D., Department of Management, Faculty of Management and Transport, University of Bielsko-Biala. Email: kpiskrzynska@ath.bielsko.pl. 
The World Health Organization has set the priority to improve the quality of health care. For the aim to be achieved, hospitals should try hard to meet the expectations of customers and to perform their duties reliably. In the sphere of medical service quality is conditioned by the state of health.

Peterman and Cella presented the list of assessment elements involved in quality of life of the conditioned state of health. They are as follows (Steuden \& Okła, 2007, pp. 6-7):

(1) Physical well-being, including ailments;

(2) Functional well-being, expressing the ability to participate in daily activities associated with work and rest;

(3) Emotional well-being including positive and negative emotional states;

(4) Ability to sustain relationships and family contacts;

(5) Functioning in social roles and satisfaction with their performance;

(6) Satisfaction with treatment;

(7) Sphere of intimacy and one's own body.

The quality of medical services raises many doubts. Sometimes patients are unaware of the "quality". They do not know how to evaluate it and are not able to measure it. The quality of medical services is committed to ensuring that all activities are at the highest level, in accordance with applicable standards.

\section{Customer Satisfaction}

Customer satisfaction is a key factor for identifying why customers abandon the services of the company, go to the competition or remain as loyal customers (Cohen, Gan, Au Yong, \& Choong, 2006).

The company will succeed in the market, and its business will be profitable when their customers are satisfied (Shin \& Elliott, 2001). Satisfaction has its reasons but it also has consequences for: emotional, declarative, and behavioral sphere (Biesok \& Wyród-Wróbel, 2016, p. 7).

According to the Dictionary of Foreign Words, satisfaction (lat. = Satisfactio - satisfaction) is the "feeling of pleasure, contentment (e.g., in doing something), restitution, compensating harm" (Dictionary of Foreign Words, 2012, p. 668).

One of the customer satisfaction survey methods is the method of Customer Satisfaction Index (CSI). Patterns used in this method are shown in Table 1.

Table 1

Indicators in the Method of CSI

\begin{tabular}{|l|l|l|l|}
\hline $\begin{array}{l}w_{i}: \text { importance rate } \\
i: \text { of the element }\end{array}$ & $\begin{array}{l}\text { CSI index (customer } \\
\text { satisfaction) }\end{array}$ & $\begin{array}{l}\text { CSI max: maximum attainable } \\
\text { CSI index }\end{array}$ & The percentage index of CSI \\
\hline$w_{i}=\frac{\sum_{j=1}^{K} w_{j}}{\sum_{i=1}^{N} \sum_{j=1}^{K} w_{i j}}$ & $C S I=\sum_{i=1}^{N} w_{i}^{*} C_{i}$ & $C S I_{\max }=\sum_{i=1}^{N} w_{i}^{*} C_{i \max }$ & $C S I_{\%}=\frac{C S I}{C S I_{\max }} * 100 \%$ \\
\hline
\end{tabular}

Notes. Source: Wolniak and Skotnicka-Zasadzień (2008). $j$ : another client; K: the sum of customers surveyed; $i$ : the number of the next requirements; $N$ : the number of subjects requirements; $w_{i}$ : the importance of the parameter (weight); $c_{i}$ : the evaluation of customer satisfaction with $i$ (the requirements); $C_{i \max }$ : the maximum possible rating of $i$ (the requirement); $C S I_{\%}$ : CSI value expressed in \%; and $\mathrm{CSI}_{\max }$ : the maximum obtainable CSI index. 
CSI method allows measuring and analyzing customer satisfaction in terms of individual characteristics relevant to his/her satisfaction, and of the whole product or service. CSI survey method gives an answer to the following questions (Wolniak \& Skotnicka-Zasadzień, 2008, p. 77):

(1) What are your expectations concerning the product/service?

(2) Which of these expectations have the greatest value for the customer?

(3) To what extent does the product/service meet those expectations?

(4) Which elements should be invested in and developed, and which are overinvested?

The method of CSI is based on a survey of consumer satisfaction. CSI index measures customer satisfaction in the area of validity, as well as the consumer requirements and expectations satisfaction. Then, the results are averaged to determine the overall rate of satisfaction with a variety of characteristics. The resulting number can be represented nominally as a certain number of points or percentage. This combination allows making comparisons between companies operating in the same industry.

\section{CSI Survey Method for the Analysis of Patients Satisfaction in the Maternity Ward of the Provincial Hospital in Bielsko-Biala}

\section{Research Methodology}

This part of the article presents the results of patients satisfaction measurement in the maternity ward of the Regional Hospital in Bielsko-Biala (the study was of pilot nature - it was about validation of research and testing procedure for future research in this area).

Previously, the authors of the article analyzed the three selected maternity units at the following hospitals:

(1) County Hospital in Zywiec;

(2) Dr Gawlik Hospital District in Sucha Beskidzka;

(3) Provincial Hospital in Bielsko-Biala.

The results presented in the article show only the desirability of applying CSI methods to improve the quality of services and patients satisfaction. The study was conducted between February 15, 2015 and May 15, 2015. There were 80 questionnaires - only some of them were handed in to the respondents, whereas the remaining questionnaires were posted on the website (http://moje-ankiety.pl/respond-55298.html). Only 47 questionnaires were filled, though:

(1) The District Hospital in Zywiec, 15 questionnaires were filled;

(2) The Regional Hospital in Sucha Beskidzka, 20 questionnaires were filled;

(3) The Provincial Hospital in Bielsko-Biala, 12 questionnaires were filled.

In the initial phase of the study, 80 patients were considered to be the optimal number of respondents, but time showed that it was difficult to get involved so many patients. The questionnaire link was published on various online forums and social networking site Facebook.

\section{Research Procedures}

The research process included the following steps:

(1) The diagnosis criteria for customer satisfaction: exploration stage developed in a group interview with women who both gave birth earlier in one of the hospitals, as well as potential future patients;

(2) Prioritization for selected indicators: the assignment scale given by each respondent ranging from 1 to 4 , where 1 = a feature of little significance, $4=\mathrm{a}$ feature of great importance. A fragment of the questionnaire is given in Table A1 in Appendix A; 
(3) Assessment made by respondents of each criterion with respect to the characteristics studied in the adopted scale: 5-point adopted scale, where 1 marks the failing grade and 5 means very good. A fragment of the questionnaire is given in Table A2 in Appendix A.

Table 2

Summary Ratings and Importance Table - Department of Obstetrics at the Provincial Hospital in Bielsko-Biala

\begin{tabular}{|c|c|c|c|c|c|}
\hline No. & Indicator & $\begin{array}{l}\text { The sum } \\
\text { of ratings }\end{array}$ & $\begin{array}{l}\text { Average } \\
\text { grade }\end{array}$ & $\begin{array}{l}\text { The sum of } \\
\text { importance }\end{array}$ & $\begin{array}{l}\text { Average } \\
\text { grade }\end{array}$ \\
\hline 1 & Room equipment, in which patients stay after the delivery & 58 & 4.833 & 43 & 3.583 \\
\hline 2 & $\begin{array}{l}\text { Hall of the delivery equipment (e.g., balls, sako sacks, bathtub, } \\
\text { shower room, etc.) }\end{array}$ & 55 & 4.583 & 46 & 3.833 \\
\hline 3 & The staff's attitude towards a patient during childbirth & 44 & 3.667 & 48 & 4.000 \\
\hline 4 & The speed and effectiveness of the response to patients' requests & 40 & 3.333 & 46 & 3.833 \\
\hline 5 & Ability to choose the labor position by a patient & 41 & 3.417 & 32 & 2.667 \\
\hline 6 & Availability of a doctor during childbirth & 47 & 3.917 & 47 & 3.917 \\
\hline 7 & Discretion in childbirth & 47 & 3.917 & 33 & 2.750 \\
\hline 8 & Staff's assistance with childcare & 55 & 4.583 & 44 & 3.667 \\
\hline 9 & Thoroughness of a child examination after birth & 60 & 5.000 & 48 & 4.000 \\
\hline 10 & Helping mother with the first breastfeeding & 45 & 3.750 & 44 & 3.667 \\
\hline 11 & The information on natural and artificial feeding & 47 & 3.917 & 37 & 3.083 \\
\hline 12 & Interest in the patient's health after birth & 55 & 4.583 & 48 & 4.000 \\
\hline 13 & $\begin{array}{l}\text { Board in the maternity ward (i.e., whether it is suitable for } \\
\text { nursing mothers) }\end{array}$ & 55 & 4.583 & 43 & 3.583 \\
\hline 14 & Number of patients in the childbirth halls & 55 & 4.583 & 39 & 3.250 \\
\hline 15 & Availability of nappies and clothes in the baby ward & 54 & 4.500 & 27 & 2.250 \\
\hline 16 & Visiting hours and the number of guests allowed to visit a patient & 58 & 4.833 & 41 & 3.417 \\
\hline 17 & $\begin{array}{l}\text { The possibility of staying with a child non-stop, from birth until } \\
\text { discharge }\end{array}$ & 60 & 5.000 & 48 & 4.000 \\
\hline 18 & The possibility of holding the family labor & 58 & 4.833 & 33 & 2.750 \\
\hline 19 & $\begin{array}{l}\text { The possibility to continue the treatment of the child in the } \\
\text { neonatal clinic }\end{array}$ & 58 & 4.833 & 48 & 4.000 \\
\hline 20 & The functioning of the antenatal classes & 49 & 4.083 & 42 & 3.500 \\
\hline Average & & & 4.3374 & & 3.4875 \\
\hline
\end{tabular}

Note. Source: own work.

The following criteria were selected to be analyzed:

(1) Room equipment, in which patients stay after the delivery;

(2) Hall of the delivery equipment (e.g., balls, sako sacks, bathtub, shower room, etc.);

(3) The staff's attitude towards a patient during childbirth;

(4) The speed and effectiveness of the response to patients' requests;

(5) Ability to choose the labor position by a patient;

(6) Availability of a doctor during childbirth;

(7) Discretion in childbirth;

(8) Staff's assistance with childcare;

(9) Thoroughness of a child examination after birth;

(10) Helping mother with the first breastfeeding;

(11) The information on natural and artificial feeding;

(12) Interest in the patient's health after birth; 
(13) Board in the maternity ward (i.e., whether it is suitable for nursing mothers);

(14) Number of patients in the childbirth halls;

(15) Availability of nappies and clothes in the baby ward;

(16) Visiting hours and the number of guests allowed to visit a patient;

(17) The possibility of staying with a child non-stop, from birth until discharge;

(18) The possibility of holding the family labor;

(19) The possibility to continue the treatment of the child in the neonatal clinic;

(20) The functioning of the branch antenatal classes.

In Table 2 above, the aggregated results of the evaluations and importance for the Department of Obstetrics at the Provincial Hospital in Bielsko-Biala were collected.

Further analysis is based on the following characteristics quality maps (see Figures 1 and 2).

\begin{tabular}{|c|c|c|c|}
\hline \multirow{2}{*}{ 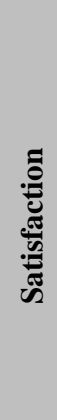 } & $\stackrel{00}{00}$ & $\begin{array}{c}\text { Factors requiring } \\
\text { improvement in the } \\
\text { shortest possible } \\
\text { period }\end{array}$ & $\begin{array}{l}\text { Factors requiring } \\
\text { maintenance and } \\
\text { monitoring }\end{array}$ \\
\hline & $\begin{array}{l}\text { స్ } \\
\text { ڤ్ }\end{array}$ & $\begin{array}{l}\text { Factors requiring } \\
\text { improvement in the } \\
\text { long term }\end{array}$ & $\begin{array}{l}\text { Minor factors which } \\
\text { do not require } \\
\text { investment }\end{array}$ \\
\hline & & Small & Big \\
\hline & & \multicolumn{2}{|c|}{ Importance of Features } \\
\hline
\end{tabular}

Figure 1. Quality map.

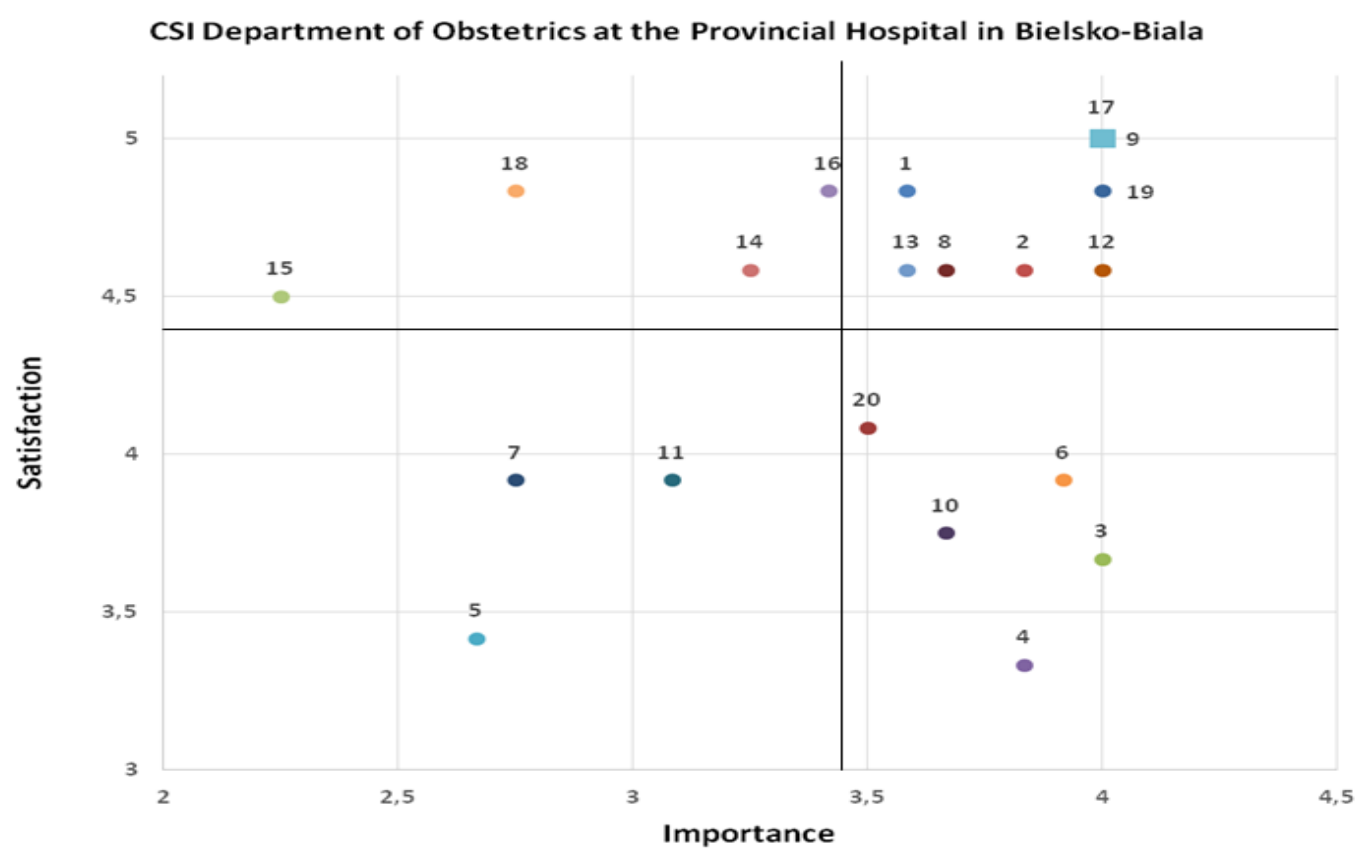

Figure 2. CSI Department of Obstetrics at the Provincial Hospital in Bielsko-Biala. Source: own work. 
Points with numbers on the matrix indicate the number of the point, from Table 2.

The study among patients in the Department of Obstetrics at the Provincial Hospital suggests that immediate improvement is required in the following aspects:

(1) Availability of nappies and clothes in the baby ward (Point 15);

(2) The possibility of holding the family labor (Point 18);

(3) Number of patients in the childbirth halls (Point 14);

(4) Visiting hours and the number of guests allowed to visit a patient (Point 16).

The respondents also pointed to the possibility of improving the functioning of antenatal classes (Point 20). However, in the long term, the hospital should take care of the following aspects:

(1) Improve the system of informing about the ways of natural and artificial feeding (Point 11);

(2) Take into account the choice of birthing positions during the birth (Point 5);

(3) Increase discretion during the delivery (Point 7).

Areas of which the quality should be maintained in this ward are primarily:

(1) Meticulous medical examination of the child shortly after the delivery (Point 9);

(2) Interest in the patient's health and the patient herself (Point 12).

Patients are also satisfied with the possibility of staying with the child 24 hours a day (Point 17), staff's assistance with a newborn care (Point 8) and the possibility of continuing the child's stay in the neonatal clinic (Point 19). Patients also pay attention to good quality facilities in the delivery room (Point 1) and the one they stay in after the labor (Point 2).

The areas of minor importance are:

(1) The functioning of the antenatal classes (Point 20);

(2) Helping mother with the first breastfeeding (Point 10);

(3) Availability of a doctor during childbirth (Point 6);

(4) The staff's attitude towards a patient during childbirth (Point 3);

(5) The speed and effectiveness of the response to patients' requests (Point 4).

CSI has been calculated using a spreadsheet excel and amounts $84 \%$.

\section{Conclusions}

The survey of consumer satisfaction is at present time an activity, without which present-day companies could not function properly and would not be able to create products suitable for their consumers. Thanks to the use of many methods of examining customer satisfaction by companies and institutions, they can adapt to the demands of consumers and also - on the basis of collected data - improve the existing situation in the enterprise, institutions and reach new costumers. In the market, we can find many companies that specialize in conducting surveys on consumer satisfaction. Nowadays, such a measurement may be subjected to almost all areas of life, but the most common is the study of consumer satisfaction on the use of a good, service quality in a person, institution or diagnosis of customer satisfaction on the service received/performed. Sometimes just one factor is enough to support the choice of the institution. The study allowed us to specify those that have the greatest impact on them. The hospital unit, as a special provider, should meet the needs of their patients and meet their expectations. 


\section{References}

Biesok, G., \& Wyród-Wróbel, J. (2016). Models of customer satisfaction. Warsaw: Publisher Difin.

Cohen, D., Gan, C., Au Yong, H. H., \& Choong, E. (2006). Customers satisfaction: A study of bank customer retention in New Zealand. Commerce Division, Discussion Paper No. 109, pp. 1-24.

Dictionary of Foreign Words. (2012). Satisfaction. Warsaw: Publisher PWN.

Flejterski, S., Panasiuk, A., Perenc, J., \& Rosa, G. (2005). Contemporary services economics. Warsaw: Publisher PWN.

Opolski, K., Dykowska, G., \& Możdżonek, M. (2005). Quality management in health services. Theory and practice. Warsaw: CeDeWu.

Shin, D., \& Elliott, K. M. (2001). Measuring customers' overall satisfaction: A multi-attributes assessment. Services Marketing Quarterly, 22(1), 3-19.

Steuden, S., \& Okła, W. (2007). Quality of life in the disease. Lublin: Publishing KUL.

Wolniak, R., \& Skotnicka-Zasadzień, B. (2008). Selected methods of customer satisfaction and supplier evaluation in organizations. Publisher Silesian University of Technology, Gliwice.

\section{Appendix A: Questionnaire}

In Table A1, please rate each of the characteristics:

$1=\mathrm{a}$ feature of little importance, $4=\mathrm{a}$ feature of great importance.

Table A1

Table example: The importance of factors

\begin{tabular}{|c|c|c|c|c|}
\hline How important is it for you? & 1 & 2 & 3 & 4 \\
\hline Room equipment, in which patients stay after the delivery & & & & \\
\hline Hall of the delivery equipment (e.g., balls, sako sacks, bathtub, shower room, etc.) & & & & \\
\hline
\end{tabular}

In Table A2, please rate each of these characteristics:

$1=$ failing grade, $5=$ very good.

Table A2

Table example: The evaluation of factors

\begin{tabular}{|c|c|c|c|c|}
\hline What is your opinion? & 1 & 2 & 3 & 4 \\
\hline Room equipment, in which patients stay after the delivery & & & & \\
\hline Hall of the delivery equipment (e.g., balls, sako sacks, bathtub, shower room, etc.) & & & & \\
\hline
\end{tabular}

